\title{
Assessment of communication CSR by Polish water and sewage companies
}

\author{
AGATA LULEWICZ-SAS, JOANNA GODLEWSKA \\ Faculty of Engineering Management \\ Bialystok University of Technology \\ 45A, Wiejska Street, 15-351 Bialystok \\ POLAND
}

\begin{abstract}
The aim of the article was to carry out analysis and evaluation of the process of communication CSR by water and sewage companies. The analysis was carried out in relation to 510 water and sewage companies located in Poland, associated in the Chamber of Commerce of "Polish Waterworks". In the theoretical part, the method of literature review was used, and in the empirical research, the method of analyzing the content of the

social responsibility concept published on the enterprises' websites was used. The obtained results allow for the conclusion that the communication carried out by the surveyed water and sewage companies in the field of corporate social responsibility should be assessed quite low. Out of 510 surveyed enterprises $63 \%$ did not inform about the implementation of activities in line with the CSR concept. Most of them conduct communication activities in the form of environmental education. Among the surveyed water and sewage companies, the biggest number of them have a well-developed and implemented systems ISO 9001, ISO 14001 and EMAS. Hence, it can be concluded that enterprises, the most often and to a very limited extent, only implement the strategy of informing about CSR activities. The research also shows that in Polish conditions there is no relationship between the implementation of formalized management systems and the concept of CSR.
\end{abstract}

Key-Words: corporate social responsibility, water and sewage company, communication CSR Received: September 24, 2020. Revised: December 31, 2020. Accepted: January 2, 2021. Published: January 8, 2021

\section{Introduction}

The concept of corporate social responsibility (CSR) is considered to be an important business imperative [1] as well as strategic enterprise management element [2]. It is interpreted to be permanent and voluntary actions undertaken by enterprises in which they integrate social and environmental aspects with business activities through interaction with their stakeholders [3]. CSR is a response to the challenges posed to the business sphere by various environments and social groups, as well as the society as a whole, struggling with serious problems, such as: environmental degradation, civilisation diseases, hunger and epidemics and unfair business practices [4]. It is treated as a tool to build competitive advantage, reduce business risk and improve the company's reputation [5], [6], [7]. In the literature on the subject it is emphasized that effectively implemented activities in the field of corporate social responsibility lead to better cooperation with subcontractors, intermediaries or other business partners, and also result in greater customer satisfaction [8], [9], [10].

Water and sewage companies, which are the subject of the research, are included in the category of public utility companies. The services provided by these enterprises are associated with a natural monopoly, as they have acquired a unique public status due to their peculiarities guaranteeing the implementation of the social interest. This means that the service providers have a specific obligation towards the recipients of these services, based on satisfying the needs at an appropriate level, so as to ensure their proper social and economic functioning. At the same time, these services are characterized by social inclusion, which is based on inclusion and not discrimination of the citizens who use them, which determines the necessity to provide these services at certain, socially acceptable prices [11].

As practice shows, monopolistic conditions for the operation of water and sewage companies are often an impulse to abuse a dominant position. This statement may be confirmed by the number of cases analyzed by the Office of Competition and Consumer Protection. In the years 2013-2014, water and sewage companies were addressees of a significant part (about 7\%) of the decisions issued by this office [12].

The issue of social responsibility as the subject of systematic scientific research is rarely analyzed in water and sewage companies. On June 25th, 2020, in 
the Web of Science database, the number of indications of the terms "corporate social responsibility" and "water supply" was 13 , and in the Scopus database 24 .

The purpose of this article is to analyze and evaluate the communication process of CSR activities by Polish water and sewage companies. The research was conducted in the fourth quarter of 2019.

The subject of the research were water supply and sewage companies located on the territory of Poland, associated in the Chamber of Commerce "Polish Waterworks"1. In empirical research, the method of analyzing the content of the concept of social responsibility published on corporate websites was used. The results presented in this article should be treated as an initial stage of work that will be continued to a greater extent.

\section{Theoretical aspects of CSR communication by enterprises}

For an organization to be recognized as socially responsible, it must make its CSR activities visible and accessible to internal and external stakeholders [13]. This goal can be achieved through appropriate communication, the importance of which is constantly growing, which is reflected in theoretical research and practical applications [14]. A. Pèrez presents the view that without communication, CSR activities, no matter how many and what kind, are perceived by stakeholders as insignificant and even regarded negative [15]. Taking into account the growing expectations of various stakeholder groups, organizations wishing to achieve a competitive advantage must engage in socially responsible activities [16]. The significance of communicating socially responsible activities is particularly important because it affects the image of the organization, allowing you to build a more positive reputation and credibility, and enables you to achieve competitive success [17], [18].

Communicating CSR activities does not happen without risk. Information about conducted CSR activities may be met with skepticism by stakeholders, who question the company's motives or even see them as a cover for non-strict behavior, which may ultimately lead to a reduction in the level of trust and a negative impact on the organization's reputation [19]. However, this risk is largely

1 The Chamber of Commerce "Polish Waterworks" is the only economic self-government organization in the water and sewage sector in Poland. It was established in 1992. The aim of the Chamber's operation is to create favourable conditions for the functioning of the water and sewage sector, in particular: current interpretation and assessment influenced by the organization itself. Stimulating the involvement of individual stakeholder groups and conducting dialogue with stakeholders ensure greater credibility of CSR activities. Effective CSR communication requires such features as informativeness, third-party endorsement, personal relevance, consistency, self-efficacy, selfpromotional message tone, and transparency [20].

Given the degree of stakeholder involvement in the CSR dialogue, the three basic CSR communication strategies can be distinguished such as: strategy for informing, responding and engaging stakeholders in CSR management (Table 1).

Table 1. Three CSR communication strategies

\begin{tabular}{|l|l|l|l|}
\hline & $\begin{array}{l}\text { The } \\
\text { Stakeholder } \\
\text { Information } \\
\text { Strategy }\end{array}$ & $\begin{array}{l}\text { The } \\
\text { Stakeholder } \\
\text { Response } \\
\text { Strategy }\end{array}$ & $\begin{array}{l}\text { The } \\
\text { Stakeholder } \\
\text { Involvement } \\
\text { Strategy }\end{array}$ \\
\hline $\begin{array}{l}\text { Communi- } \\
\text { cation ideal }\end{array}$ & $\begin{array}{l}\text { Public } \\
\text { information, } \\
\text { one-way } \\
\text { communi- } \\
\text { cation }\end{array}$ & $\begin{array}{l}\text { Two-way } \\
\text { asymmetric } \\
\text { communi- } \\
\text { cation }\end{array}$ & $\begin{array}{l}\text { Two-way } \\
\text { asymmetric } \\
\text { communic- } \\
\text { ation }\end{array}$ \\
\hline Stakeholders & $\begin{array}{l}\text { Request } \\
\text { more } \\
\text { information } \\
\text { on corporate } \\
\text { CSR efforts }\end{array}$ & $\begin{array}{l}\text { Must be } \\
\text { reassured } \\
\text { that the } \\
\text { company is } \\
\text { ethical and } \\
\text { socially } \\
\text { responsible }\end{array}$ & $\begin{array}{l}\text { Co-construct } \\
\text { corporate } \\
\text { CSR efforts }\end{array}$ \\
\hline $\begin{array}{l}\text { Stakeholder } \\
\text { role }\end{array}$ & $\begin{array}{l}\text { Stakeholder } \\
\text { influence: } \\
\text { support or } \\
\text { oppose }\end{array}$ & $\begin{array}{l}\text { Stakeholder } \\
\text { s respond to } \\
\text { corporate } \\
\text { actions }\end{array}$ & $\begin{array}{l}\text { Stakeholders } \\
\text { are involved, } \\
\text { participate } \\
\text { and suggest } \\
\text { corporate } \\
\text { actions }\end{array}$ \\
\hline
\end{tabular}

Source: [21]

The information strategy ensures one-way communication, and the stakeholder has the least influence on the implementation of socially responsible activities. The strategy of reacting and engaging provides two-way communication, thanks to which it is possible to obtain additional benefits for the organization as a result of learning the opinions of interested parties about CSR activities and communication.

Communication of CSR activities should be supported by the fact that enterprises have formalized management systems (quality management system, environmental management system, occupational

of applicable regulations, monitoring of proposed changes, participation in the creation of industry law and implementation of solutions improving the functioning of the industry. The organisation conducts consulting, training and publishing activities. One of the basic tasks is also the environment protection. 
health and safety management system). One of the requirements of formalized systems is that enterprises define both internal and external communication methods.

Formalized management systems contribute to sustainable development because they cover such areas as quality, environment and occupational health and safety [22]. Some authors also associate formalized management systems with the concept of CSR [23]. Undeniably, formalized management systems, sustainable development as well as the concept of CSR are based on three pillars: economic, environmental and social ones.

Formalized management systems are the framework for implementing CSR [24], because they contain some common elements. In the case of the environmental management system, the common element with CSR is concern for the natural environment (CSR area: environment), and in the case of the occupational health and safety management system - concern for human health (CSR area: human rights). The quality management system is based on the principles described in the ISO 9000 standard [25], such as: (1) customer focus, (2) leadership, (3) people involvement, (4) process approach, (5) improvement, (6) evidence-based decision making, (7) relationship management. These principles are compatible with the CSR areas included in the ISO 26000 standard, such as: (1) organizational governance, (2) human rights, (3) workplace practices, (4) environment, (5) market practices, (6) consumer issues; (7) community involvement and development [26].

Research conducted by L. Moratis shows that $66.1 \%$ of the enterprises that operate in accordance with ISO 9001 implement CSR activities. With regard to the environmental management system, $58.9 \%$ of enterprises operating in accordance with ISO 14001 implement CSR activities [27]. Research shows that there is an impact of the implementation of voluntary management systems on activities in the field of CSR concept [28].

\section{The specificity of water and sewage companies}

Water and sewage companies providing services related to collective water supply and sewage disposal operate under the conditions of a local natural monopoly. This position is not the result of a market struggle, but is related to the specificity of the services provided using the network and requiring high financial outlays technical infrastructure. Taking into account the capital intensity of the investment cycle, the existence of competition in the water and sewage services market from an economic point of view is not justified.

Operation under the conditions of monopoly, i.e. full domination, is also related to the specificity of services provided by water and sewage companies in the field of natural good, i.e. water, which has no substitute. On the other hand, water supply and sewage disposal are services necessary for human life and functioning, as well as for running a business.

It should also be emphasized that a feature that distinguishes water and sewage companies (similarly to other utilities) is the lack of a profit maximization motive.

Table 2. National economy entities according to legal forms and the PKD section "Water collection, treatment and supply" and "Sewage disposal and treatment" (as of December 31, 2019)

\begin{tabular}{|l|c|c|c|c|}
\hline \multirow{2}{*}{$\begin{array}{l}\text { Organizatio } \\
\text { nal-legal } \\
\text { form }\end{array}$} & \multicolumn{3}{|c|}{$\begin{array}{c}\text { Water } \\
\text { collection, } \\
\text { treatment and } \\
\text { supply }\end{array}$} & $\begin{array}{c}\text { Sewage disposal } \\
\text { and treatment }\end{array}$ \\
\cline { 2 - 5 } & $\begin{array}{c}\text { Number } \\
\text { of enter- } \\
\text { prises }\end{array}$ & $\begin{array}{c}\text { Share } \\
{[\%]}\end{array}$ & $\begin{array}{c}\text { Number } \\
\text { of enter- } \\
\text { prises }\end{array}$ & $\begin{array}{c}\text { Share } \\
{[\%]}\end{array}$ \\
\hline $\begin{array}{l}\text { state- } \\
\text { owned } \\
\text { enterprises }\end{array}$ & 1 & 0.1 & - & 0 \\
\hline $\begin{array}{l}\text { commercial } \\
\text { companies }\end{array}$ & 774 & 40.3 & 335 & 12.0 \\
\hline $\begin{array}{l}\text { civil } \\
\text { partnerships }\end{array}$ & 36 & 1.9 & 124 & 4.5 \\
\hline $\begin{array}{l}\text { water } \\
\text { companies }\end{array}$ & 316 & 16.5 & $*$ & $*$ \\
\hline cooperatives & 7 & 0.4 & 5 & 0.2 \\
\hline $\begin{array}{l}\text { natural } \\
\text { persons } \\
\text { running } \\
\text { a business }\end{array}$ & 261 & 13.6 & 2121 & 76.1 \\
\hline $\begin{array}{l}\text { budgetary } \\
\text { establish- } \\
\text { ments and } \\
\text { auxiliary } \\
\text { farms }\end{array}$ & 523 & 27.2 & $*$ & $*$ \\
\hline Total & 1918 & 100 & 2786 & 100 \\
\hline
\end{tabular}

*no data

Source: own study based on [29] and information provided by the Polish Waterworks Chamber of Commerce.

In REGON (the National Business Registry Number), water and sewage companies are registered in two PKD (Code List of Classification of Business 
Activities) sections: Water collection, treatment and supply and Wastewater collection and treatment. In 2019, 1918 entities were registered in the section Water collection, treatment and supply and 2786 entities in the section Wastewater discharge and treatment. The organizational-legal forms of business entities from both sections are presented in Table 2.

The largest group of entities performing tasks in the field of water collection, treatment and supply are commercial companies (over 40\%), budgetary establishments (nearly 28\%), water companies (16\%) and natural persons running a business (nearly 14\%). Other organizational forms, such as state-owned enterprises, civil partnerships and cooperatives constitute together $2.4 \%$.

In the wastewater collection and treatment department in 2019, the largest group were natural persons running a business (over 76\%). Commercial companies in this section represent $12 \%$, and civil partnerships $4.5 \%$. The share of the cooperatives is negligible, it is only $0.2 \%$.

The share of natural persons in this section (2 121 entities, i.e. over $76 \%$ ) may seem surprisingly high compared to the same group of entities dealing with water collection, treatment and supply (261 entities). It is related to the fact that section of PKD 37.00.Z includes such sections as cesspit tank cleaning or sewage delivered to collection points, which is often handled by small entities. This confirms that in the analysis of the water supply and sewage industry it is more justified to use data from the section water collection, treatment and supply [30].

\section{Research method}

The aim of the research was to analyze and evaluate the communication of CSR activities by water and sewage companies. The subject of the research were water supply and sewage companies located on the territory of Poland, associated in the Chamber of Commerce "Polish Waterworks"2 (at present, the Chamber has 510 water and sewage market companies - 476 ordinary members and 34 associate members). The studied sample accounts for $10.8 \%$ of all the Polish water and sewage companies.

In empirical research, the method of analyzing the content of the concept of social responsibility published on corporate websites was used. The scope

\footnotetext{
2 The Chamber of Commerce "Polish Waterworks" is the only economic self-government organization in the water and sewage sector in Poland. It was established in 1992. The aim of the Chamber's operation is to create favourable conditions for the functioning of the water and sewage sector, in particular: current interpretation and assessment
}

of the research included investigating whether the enterprise:

- has a CSR tab on its website;

- informs about its CSR strategy;

- publishes CSR reports;

- has a developed code of ethics;

- has implemented a formalized management system (ISO 9001, ISO 14001, OHSAS 18001, PN-N 18001, ISO 45001, ISO 22000)

- conducts customer satisfaction surveys;

- conducts environmental, pro-social and sponsoring activities.

The research results are therefore determined by the availability, timeliness and reliability of information presented by the enterprises.

The conducted research included drawing conclusions on the basis of an open information message (on the basis of a website), including identification, selection and coding of information on the social responsibility of the surveyed enterprises.

The specific objectives of the research are:

- identification and assessment of methods of communication of socially responsible activities conducted by enterprises;

- identification of formalized tools for implementing the concept of socially responsible activity.

Based on the literature review, two research hypotheses were proposed:

H1: An important aspect of the CSR concept is communicating about the implemented socially responsible activities.

$\mathrm{H} 2$ : The existence of formalized management systems in water and sewage companies has a positive impact on the implementation of the CSR concept.

The research was conducted in the fourth quarter of 2019.

\section{Findings and discussion}

Based on the analysis of the websites of 510 water and sewage companies, it can be concluded that only 189 companies (i.e. $37 \%$ of companies associated in the "Polish Waterworks" Chamber of Commerce) presented information in line with the concept of social responsibility on their websites.

The conducted research in the field of communication of socially responsible activities by

of applicable regulations, monitoring of proposed changes, participation in the creation of industry law and implementation of solutions improving the functioning of the industry. The organisation conducts consulting, training and publishing activities. One of the basic tasks is also the environment protection. 
water and sewage companies showed that enterprises are not very active in this respect. Out of 510 surveyed enterprises, 321 (63\%) did not inform about the implementation of activities in line with the CSR concept, $16(3 \%)$ enterprises directly inform about the implementation of the CSR concept, and only one company implements the CSR concept based on the guidelines of ISO 26000 [36]. The most important sources of communication in the area of CSR are presented in Figure 1.

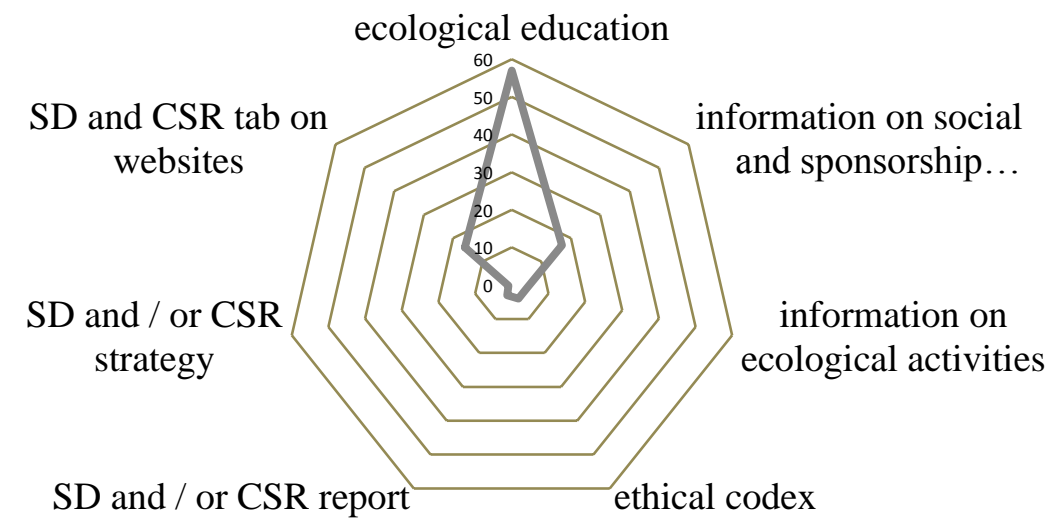

Figure 1. CSR activities communication Source: own study.

Most of the enterprises (57 entities, which constitute $11.2 \%$ of the surveyed sample) conduct communication activities in the form of environmental education. These are both educational content on the quantity and quality of water resources, water saving and water protection, as well as information on educational activities carried out: workshops, festivals, competitions, cyclical or oneoff actions. In the second place, water and sewage companies inform about the undertaken pro-social and sponsoring activities (17 companies, which constitutes $3.3 \%$ ). Examples of such activities are: installing water curtains in cities, drinking bottles in schools, providing water aerators with additives at mass events, organizing and sponsoring sports events, developing the information society by introducing and improving e-services. Only 16 companies $(3.1 \%)$ have a special tab on their website dedicated to CSR activities. Definitely few, because only 4 enterprises (less than $1 \%$ of the surveyed sample) publish a code of ethics. The same number of entities inform about conducted environmental activities. They concern the development of the circular economy, including the creation of closed water cycles, composting sewage sludge or the use of renewable energy sources, e.g. photovoltaics or the recovery of biogas from sewage sludge. Only 3 enterprises publish a CSR report or a sustainable development report, and only one enterprise in the entire surveyed sample has published a document of a sustainable development and responsible business strategy. Only one company has also developed standards for corporate social responsibility. Polish enterprises do very poorly in terms of communication of CSR activities compared to foreign enterprises. The survey of 28 water and sewage companies conducted in 4 countries (Denmark, The United Kingdom, The United States and South Africa) shows that $89.3 \%$ of them have a CSR policy published on their website, and $82.1 \%$ - a CSR report [31]. On the other hand, the study of non-financial reports conducted in Czech shows that environmental information are least often published there by large corporations [32].

The analysis of the obtained results shows that the surveyed companies communicate their CSR activities to a very poor degree. This does not mean that they do not carry out such activities, but they certainly do not inform about them via their websites. According to research results obtained in banking sector corporate websites in CSR communication would seem to be an appropriate environment to offer 
both the chance to report on CSR programs and to create a forum for feedback for stakeholders [33].

Activities in the area of CSR "consumer issues" include having an online customer service office (114 companies $-22.3 \%$ ), the introduction of e-invoices (64 companies - 12.5\%) and customer satisfaction surveys (19 companies - 3.7\%). These are activities resulting mainly from the implementation of the ISO 9001 quality management system.

The conducted research also allowed to check whether there is a relationship between the implementation of formalized management systems, such as the quality management system, environmental management system and occupational health and safety management system, and the CSR concept. The results of the research regarding the possession of formalized CSR implementation tools are presented in Table 3.

Table 3. Formalized tools for the implementation of the CSR concept

\begin{tabular}{|l|c|}
\hline \multicolumn{1}{|c|}{ Type of formalized system } & $\begin{array}{c}\text { Number } \\
\text { of } \\
\text { enterprises }\end{array}$ \\
\hline $\begin{array}{l}\text { Quality management system } \\
\text { (ISO 9001) }\end{array}$ & 53 \\
\hline $\begin{array}{l}\text { Environmental management system } \\
\text { (ISO 14 001) }\end{array}$ & 37 \\
\hline $\begin{array}{l}\text { Eco-management and audit system } \\
\text { (EMAS) }\end{array}$ & 2 \\
\hline $\begin{array}{l}\text { Occupational health and safety } \\
\text { management system (OHSAS 18001, } \\
\text { PN-N 18001, ISO 45001) }\end{array}$ & 14 \\
\hline Food safty management (ISO 22000) & 3 \\
\hline
\end{tabular}

Source: own study.

Among the 510 surveyed water and sewage companies, the biggest number of them have a welldeveloped and implemented quality management system ISO $9001(10.4 \%)$ and the environmental management system ISO 14001 and EMAS (7.6\%). It can be seen that the indicator of having any other formalized management system is the quality management system. In the analyzed sample, there is no enterprise which would have a system and no quality management system. Therefore, it can be assumed that this is the first step towards achieving CSR goals.

Analyzing the behavior of 53 enterprises that have any formalized management system, only 13 of them conduct environmental education. As many as 44 other enterprises conducting environmental education do not have any formalized management system, either developed or implemented. Thus, it can be concluded that conducting environmental education is not related to having management systems. They do not affect the propensity of entities to conduct environmental education. This is a disturbing phenomenon, because the assumptions of the ISO 14001 system show that it raises the environmental awareness of management and employees, and consequently, they are more willing to pass these values and knowledge to their environment. This conclusion is also confirmed by the fact that only 3 enterprises from this group, which have formalized management systems, undertake social and sponsoring initiatives. The remaining 14 undertake them, but there are no well-developed and implemented management systems. Additionally, only 5 companies in the analyzed group have a tab with CSR content on their website. The remaining 10 companies have such a tab, but no management systems. This unfavorable phenomenon of the lack of correlation between the possession of a management system and CSR activities is only mitigated by the fact that in the group of enterprises with implemented management systems, 3 of them (out of all 4) conduct pro-ecological activities.

In addition to the management systems mentioned above, water and sewage companies also implement the ISO 22000 Food safety management system, the primary goal of which is to take responsibility for the product, i.e. water. From among the respondents, only three companies report the implemented system in this regard. The factor determining the activities of water and sewage companies in the field of CSR is therefore the law [34], and not voluntary actions in line with the CSR concept.

\section{Conclusions}

Modern enterprises, in order to meet the needs and expectations of stakeholders, should go beyond the obligations imposed by the law and implement voluntary activities in line with the concept of CSR. Among such enterprises are water and sewage companies that provide services that meet the two fundamental needs that form the basis of Maslow's pyramid, namely the physiological and safety needs for the supply of quality water and the sewage collection.

The analysis carried out as part of this article shows that the implementation of the CSR concept in the surveyed water and sewage companies substantially is not carried out as a planned long-term strategy of action, but as separate, individual actions undertaken ad hoc.

The conducted research did not confirm the truth of the hypothesis 1 that An important aspect of the CSR concept is communicating about the implemented socially responsible activities. Such a 
low interest in the implementation of CSR by the analyzed companies may be caused by the monopolistic position of the water and sewage sector, which results in no need to compete with other entities or the desire to stand out.

Communication carried out by the surveyed water and sewage companies in the field of social responsibility should be assessed quite low. The analysis shows that enterprises most often and to a very limited extent implement the strategy of informing about CSR activities. The strategy for reacting and engaging stakeholders should be considered a challenge to be implemented in the near future.

The theoretical considerations did not confirm the truth of the hypothesis 2 that The existence of formalized management systems in water and sewage companies has a positive impact on the implementation of the CSR concept. Based on the conducted research, it can be concluded that there is no difference between the implementation of formalized management systems and the implementation of the CSR concept.

The website survey provided information on the scope of communicating CSR activities by water and sewage companies. However, it cannot be concluded on this basis whether this concept is implemented by them, and if so, to what extent. Therefore, it is necessary to conduct in-depth research on this sector of the economy, the more so as public utility enterprises, by definition, serve the society and should play a model role in pro-social and proenvironmental activities.

The website survey provided information on the scope of communicating CSR activities by water and sewage companies. This method was also used by $\mathrm{T}$. Dąbrowski in his research. It allows to obtain only preliminary results on communicating CSR by economic entities. He also points out that further research should focus on analyzing the content of the pages that allows to determine the length of the published messages, determine their semantic content, or identify the impression management techniques used in them.[35].

Basing on obtained research results, it cannot be concluded whether the CSR concept is implemented by studied entities, and if so, to what extent. Therefore, it is necessary to conduct in-depth research on this sector of the economy, the more so as public utility enterprises, by definition, serve the society and should play a model role in pro-social and pro-environmental activities.

\section{References:}

[1] Carvalho S. W., Sen S., de Oliveira M. M., \& de Lima R. C., Consumer reactions to CSR: A Brazilian perspective, Journal of Business Ethics, Vol.91, No.2, 2010, pp. 291-310.

[2] Rahman F., \& Norman R. T., The effect of firm scale and CSR geographical scope of impact on consumers' response, Journal of Retailing and Consumer Services, Vol.28, 2016, pp. 189-198.

[3] Neal A., Corporate social responsibility: Governance gain or laissez-faire figleaf?, Comparative Labor Law and Policy Journal, Vol. 29, No.4, 2008, pp. 459-474.

[4] Szwajca D., \& Nawrocki T.L., Possibility of Assessing Companies' Commitment to Socially Responsible Activities and Their Information Policy Regarding CSR, Organization Review, Vol.4, 2016, pp. 44-52.

[5] Weber M., The business case for corporate social responsibility: A company level measurement approach for CSR, European Management Journal, Vol.26, No.4, 2008, pp. 247-261.

[6] Lulewicz-Sas A., Evaluation of socially responsible activities of enterprises, Publishing House of the Białystok University of Technology, 2016.

[7] Liu L., Li S., \& Opara M., Corporate social responsibility and strategic company behaviour: CVS Health's discontinuation of tobacco products, Corporate Social Responsibility and Environmental Management, Vol.25, No.4, 2018, pp. 1293-1305.

[8] Sprinkle G.B., \& Maines L.A., The benefits and costs of corporate social responsibility, Business Horizons, Vol.53, No.5, 2010, pp. 445-453.

[9] Kreng V.B., \& Huang M.Y., Corporate Social Responsibility: Consumer Behavior, Corporate Strategy and Public Policy, Social Behavior and Personality, Vol.39, No.4, 2011, pp. 529-542.

[10] Wachowiak P. Enterprise social sensitivity: analysis and measurement, SGH Publishing House, 2013.

[11] Famielec J., Kożuch M., \& Wąsowicz K., Public utility companies, CeDeWu, 2019.

[12] Czapliński M. Water supply and sewage guidebook. Review of issues in the light of the OCCP's decisions, Office of Competition and Consumer Protection, 2016.

[13] Ajayi O.A. \& Mmutle, T. Corporate reputation through strategic communication of corporate social responsibility, Corporate Communications: An International Journal, 2020, https://doi.org/10.1108/CCIJ-02-2020-0047.

[14] Pollach I., Johansen T.S., Nielsen A.E., \& Thomsen C., The integration of CSR into corporate communication in large European companies, 
Journal of Communication Management, Vol.16, No.2, 2012 pp. 204-216.

[15] Pèrez A., Corporate reputation and CSR reporting to stakeholders: Gaps in the literature and future lines of research, Corporate Communications: An International Journal, 2015, Vol.20, No.1, pp.1129.

[16] Du S., Bhattacharya C.B., \& Sen S., Maximizing business returns to corporate social responsibility (CSR): the role of CSR communication, International Journal of Management Reviews, 2010, Vol.12 No.1, pp. 8-19.

[17] Chernev A., \& Blair S., Doing well by doing good: the benevolent halo of corporate social responsibility, Journal of Consumer Research, Vol.41 No.6, 2015, pp. 1412-1425.

[18] Pfau M., Haigh M. M., Sims J., \& Wigley S., The Influence of Corporate Social Responsibility Campaigns on Public Opinion, Corporate Reputation Review, Vol.11, No.2, 2008, pp. 145-154.

[19] Cho S., \& Hong Y., Netizens'evaluations of corporate social responsibility: content analysis of CSR news stories and online readers' comments, Public Relations Review, Vol.35, No.2, 2009, pp. 147-149.

[20] Kima S., \& Ferguson M. A. T., Dimensions of effective CSR communication based on public expectations, Journal of Marketing Communications, Vol.24, No.6, 2018, pp. 549-567.

[21] Morsing M., \& Schultz M., Corporate social responsibility communication: stakeholder information, response and involvement strategies. Business Ethics: A European Review, Vol.15, No.4, 2006, pp. 323-338.

[22] Morsing M., \& Schultz M., Corporate social responsibility (CSR) communication and small and medium sized enterprises: The governmentality dilemma of explicit and implicit CSR communication, Human Relations, Vol.72, No.12, 2019, pp. 1920-1947.

[23] Mežinska I., Lapina I., \& Mazais J. Integrated management systems towards sustainable and socially responsible organization, Total Quality Management \& Business Excellence, Vol.26, No. 56, 2015, pp. 469-481.

[24] Bernal-Conesa J.A., Briones-Peñalver A.J. \& De Nieves-Nieto C., The integration of CSR management systems and their influence on the performance of technology companies, European Journal of Management and Business Economics, Vol.25, 2016, pp. 121-132.

[25] EN-ISO 9001:2015, Quality Management Systems - Requirements, ISO, 2015.

[26] ISO 26000:2010 Guidance for Social Responsibility, ISO, 2010.
[27] Moratis L., The (In)credible Bulk: The Role of CSR Standards in Enhancing the Credibility of Corporate CSR Claims, in: (eds.) Aluchna M., \& Idowu S.O., The Dynamics of Corporate Social Responsibility. A Critical Aproach to Theory and Pratice, Springer, 2017, pp. 239-263.

[28] Mijatovic I. S., \& Stokic D., The Influence of Internal and ExternalCodes on CSR Practice: The Caseof Companies Operating in Serbia, Journal of Business Ethics, Vol.94, 2010, pp. 533-552.

[29] Structural changes of groups of entities of the national economy in the REGON register 2019, Statistics Poland, 2020.

[30] Wojnowska M., Who we are, how we operate new data from the Statistics Poland on the water and sewage industry, Water Supply and Sewage Systems, Vol.9, No. 163, 2017, pp. 26-27.

[31] Lauesen L. M., How well are water companies engaged in CSR? A critical cross-geographical discourse analysis, Social Responsibility Journal, Vol.10, No.1, 2014, pp. 115-136.

[32] Sedláček J., Non-financial reporting of corporations - a Czech case study, WSEAS Transactions on Business and Economics, Vol.17, 2020, pp. 514-522.

[33] Palazzo M., Vollero A. \& and Siano A., From strategic corporate social responsibility to value creation: an analysis of corporate website communication in the banking sector, International Journal of Bank Marketing, 2020, https://doi.org/10.1108/IJBM-04-2020-0168.

[34] Lauesen L. M., CSR in publicly owned enterprises: opportunities and barriers, Social Responsibility Journal, Vol. 7, No.4, 2011, pp. 558577.

[35] Dąbrowski T. J., The role of websites in communicating CS policy by public companies listed on the Warsaw Stock Exchange, Polityki europejskie, finance i marketing, Vol.22, No.71, 2019, pp. 50-64.

\section{Sources of funding for research presented in a scientific article or scientific article itself}

The research is supported by Bialystok University of Technology and financed from a subsidy provided by the Minister of Science and Higher Education.

\section{Creative Commons Attribution License 4.0 (Attribution 4.0 International, CC BY 4.0)}

This article is published under the terms of the Creative Commons Attribution License 4.0

https://creativecommons.org/licenses/by/4.0/deed.en_US 